\title{
SIKAP TOLERANSI SOSIAL PADA SISWA KELAS VIII SMP BHINA KARYA GUNUNG KIDUL
}

\author{
Oleh: \\ Nuryati* Parman* \\ Universitas Cokroaminoto Yogyakarta
}

\begin{abstract}
Abstrak
Penelitian ini bertujuan untuk mendapatkan gambaran umum sikap toleransi anak menghadapi konflik antar sesama siswa pada siswa kelas VIII Sekolah SMP Bhina Karya Rongkop Kabupaten Gunungkidul. Penelitian ini menggunakan pendekatan deskriptif kualitatif. Variabel yang diteliti dalam penelitian ini adalah variabel tunggal yaitu sikap toleransi anak menghadapi konflik antar sesama siswa. Subyek penelitian yang dipilih untuk penelitian adalah siswa kelas VIII SMP Bhina Karya yang berjumlah 18 siswa. Teknik pengumpulan data menggunakan observasi dan wawancara. Data yang diperoleh selanjutnya diolah menggunakan langkah-langkah: reduksi data, display data, dan penarikan kesimpulan. Hasil penelitian ini menunjukkan bahwa: 1) Siswa mampu mengetahui tujuan dan siswa lain yang berbeda kepentingan, 2). Siswa mampu mengompromikan tujuannya sendiri dengan tujuan siswa lain, 3) Siswa bersedia menilai pendapat siswa lain, 4). Siswa yang mampu menilai pendapat siswa lain, benar atau salah, 5). Siswa yang bersedia menerima kebenaran pendapat orang lain, dan 6). Siswa yang bersedia memberikan saran atas kekurangan orang lain.
\end{abstract}

Kata kunci : Sikap Toleransi, Siswa.

\section{Pendahuluan}

Pada era globalisasi, perilaku kekerasan semakin hari semakin nampak, dan sungguh sangat mengganggu ketenteraman hidup kita. Hal tersebut tampak dari kejadian-kejadian seperti pertengkaran akibat perbedaan pendapat, perkelahian, bahkan sampai dengan pembunuhan. Perilaku kekerasan tersebut sangat mengganggu karena dengan kekerasan persoalan tidak akan terselesaikan. Kekerasan akan menimbulkan dendam sehingga persoalan akan semakin jauh dari penyelesaian. Jika hal ini dibiarkan, tidak ada upaya sistematik untuk mencegahnya, tidak mustahil kita sebagai bangsa akan menderita kerugian yang besar akibat buruk dan maraknya perilaku kekerasan di masyarakat. Saat ini kita sebagai bangsa sudah dituding oleh beberapa negara lain sebagai sarang teroris, terlepas dari benar tidaknya tudingan itu. Dalam era global seperti saat ini arus informasi tidak bisa dibendung lagi. Keadaan ini juga akan mendorong suburnya perilaku kekerasan dalam masyarakat kita. Melalui arus informasi yang bebas itulah 
pesan-pesan kekerasan ikut masuk ke dalam sistem kehidupan masyarakat kita secara tidak sadar. Seseorang menampilkan perilaku kekerasan sebagai hasil belajar juga, langsung maupun tidak langsung. Seseorang tersebut belajar dari lingkungan sekitarnya. Oleh karenanya pendidikan kita harus peduli terhadap upaya untuk mencegah perilaku kekerasan secara dini melalui program pendidikan agar budaya damai, sikap toleransi, empati, dan sebagainya dapat ditanamkan kepada peserta didik semenjak mereka berada di tingkat pendidikan prasekolah maupun pada tingkat Pendidikan Dasar.

Masyarakat Indonesia memeluk berbagai agama dan keyakinan yang berbeda berarti siswa harus ditumbuhkan sikap toleransi. Pendidikan yang diarahkan untuk mengajarkan sikap toleransi kepada anak-anak sangat penting. Hal ini dikarenakan: (1). Berbagai bentuk konflik bukan tidak mungkin untuk dapat dihindarkan. Hal ini dikarenakan seseorang pasti tidak akan terlepas dari munculnya konflik dengan orang yang lain. (2). Kebutuhan untuk mencegah konflik semakin urgen karena jika tidak diselesaikan konflik akan menimbulkan konflik baru yang lebih besar; dan (3). Pencegahan konflik adalah sangat mungkin untuk dapat dilakukan.

Persoalan yang sering dihadapi dalam pencegahan konflik yang kemudian berakibat munculnya berbagai bentuk kekerasan ialah dibiarkannya konflik itu terjadi tanpa ada upaya pencegahan yang bersifat kultural, edukatif, dan pedagogis. Dunia ini dalam keadaan bahaya bukan karena adanya kelompok orang tertentu melakukan berbagai kekerasan, tetapi justru disebabkan oleh orang-orang yang tahu adanya berbagai kekerasan tetapi tidak melakukan pencegahan apapun. Secara teoritik ada banyak cara untuk penyelesaian konflik. Penyelesaian konflik dengan cara menyerah begitu saja dengan segala kerendahan hati, melarikan diri dan persoalan yang mengakibatkan konflik, membalas musuh dengan kekuatan dan kekerasan yang jauh lebih dahsyat, menuntut melalui jalur hukum, dan lain sebagainya. Cara-cara tersebut sering tidak efektif, dan selalu ada yang menjadi korban. Salah satu upaya penyelesaian konflik adalah dengan penyelesaian konflik. Bentuk-bentuk penyelesaian konflik perlu kita jadikan program pendidikan integratif agar para siswa sebagai calon pewaris dan generasi penerus tata kehidupan masyarakat memiliki budaya damai dan mampu menegakkan perilaku anti kekerasan. Hanya melalui generasi penerus yang mampu menegakkan budaya damai dan anti kekerasan kita akan berhasil membangun masyarakat masa depan yang bisa tumbuh secara beradab dan demokratis. Sebaliknya generasi penerus yang tidak mampu melakukan penyelesaian konflik akan terdorong ke kawasan kehidupan masyarakat yang anarkis dan dalam jangka panjang masyarakat yang 
demikian itu akan terisolir dari percaturan global. Diperlukan pembelajaran berbagai bentuk penyelesaian konflik dan sikap toleransi kepada para siswa seperti dengan bermusyawarah untuk mencari solusi, cara menentukan tujuan secara bersama, dan lain sebagainya. Untuk ini guru dapat menggunakan pendekatan simulasi, bermain peran, observasi, penanganan kasus, dan lain sebagainya. Agar para siswa memiliki pengalaman nyata untuk melibatkan diri dalam mensosialisasikan gerakan anti kekerasan. Dengan demikian untuk mendidik siswa agar bisa menerima gagasan dan perilaku anti kekerasan, berbagai bentuk penyelesaian konflik sebagaimana dijelaskan diatas perlu diperkenalkan kepada siswa dalam proses belajar mengajar dikelas secara terintegrasi bukan secara monolotik.

Pembelajaran sikap toleransi dan upaya penyelesaian konflik tidak perlu kurikulum secara khusus. Hal ini dikarenakan materi penyelesaian konflik sudah ada di dalam mata pelajaran pendidikan kewarganegaraan ataupun pendidikan agama. Pembelajaran sikap toleransi dan upaya penyelesaian konflik cukup dilakukan oleh guru yang memiliki kepedulian dan komitmen yang kuat untuk menanamkan sikap dan nilai anti kekerasan kepada para siswa dengan cara mengajarkan berbagai bentuk penyelesaian konflik secara terintegrasi dengan bidang studi yang relevan dengan sifat dan hakikat penyelesaian konflik yang dikonseptualisasikan. Dengan cara ini maka dalam jangka panjang para siswa kita memiliki nilai dan perilaku anti kekerasan. Hal ini dapat dilaksanakan, sungguh kita sebagai bangsa akan memiliki generasi penerus yang santun dalam berperilaku, cerdas dalam berpikir, dan toleransi terhadap berbagai pluralitas yang ada dalam kehidupan sehari-hari. Sikap toleransi ini penting agar dikemudian hari anak-anak dapat menghadapi perbedaan yang ada di masyarakat tanpa harus menghasilkan kekerasan. Toleransi adalah persoalan yang sering dihadapi dalam pencegahan konflik yang kemudian berakibat munculnya berbagai bentuk kekerasan ialah dibiarkannya konflik itu terjadi tanpa ada upaya pencegahan yang bersifat kultural, edukatif, dan pedagogis.

\section{Metode Penelitian}

Penelitian ini menggunakan pendekatan kualitatif deskriptif Penelitian kualitatif adalah penelitian yang datanya bukan berupa angka, sedangkan penelitian deskriptif dimaksudkan untuk membuat suatu gambaran dan tidak dimaksudkan untuk menguji hipotesis tertentu, tetapi hanya 
menggambarkan hubungan-hubungan antara gejala yang satu dengan yang lain. Penelitian ini termasuk dalam jenis penelitian bidang sosial.

1. Tempat dan Waktu Penelitian

Tempat penelitian adalah di SMP Bhina Karya Rongkop Kabupaten Gunungkidul Yogyakarta. Waktu penelitian dilakukan mulai bulan September sampai dengan bulan November dan dibuat jadwal sebagai berikut:

\begin{tabular}{|c|c|c|c|c|c|c|c|c|c|c|c|c|c|c|}
\hline \multirow{2}{*}{ No } & \multirow{2}{*}{ Uraian } & \multicolumn{4}{|c|}{ September } & \multicolumn{4}{|c|}{ Oktober } & \multicolumn{4}{|c|}{ November } & \multirow{2}{*}{ Des } \\
\hline & & M1 & M2 & M3 & M4 & M1 & M2 & M3 & M4 & M1 & M2 & M3 & M4 & \\
\hline 1 & $\begin{array}{l}\text { Pengajuan } \\
\text { Judul }\end{array}$ & & $\sqrt{ }$ & $\sqrt{ }$ & & & & & & & & & & \\
\hline 2 & $\begin{array}{l}\text { Pengajuan } \\
\text { Proposal }\end{array}$ & & $\sqrt{ }$ & $\sqrt{ }$ & $\sqrt{ }$ & $\sqrt{ }$ & & & & & & & & \\
\hline 3 & $\begin{array}{l}\text { Pengajuan Bab } \\
\text { I, II, III, IV }\end{array}$ & & $\sqrt{ }$ & $\sqrt{ }$ & $\sqrt{ }$ & $\sqrt{ }$ & & & & & & & & \\
\hline 4 & $\begin{array}{l}\text { Pengambilan } \\
\text { Data }\end{array}$ & & & $\sqrt{ }$ & $\sqrt{ }$ & $\sqrt{ }$ & $\sqrt{ }$ & $\sqrt{ }$ & $\sqrt{ }$ & & & & & \\
\hline 5 & $\begin{array}{l}\text { Menganalisis } \\
\text { Data }\end{array}$ & & & & & & & $\sqrt{ }$ & $\sqrt{ }$ & $\sqrt{ }$ & $\sqrt{ }$ & $\sqrt{ }$ & $\sqrt{ }$ & \\
\hline
\end{tabular}

\section{Variabel Penelitian}

a. Variabel yang diteliti dalam penelitian ini adalah variabel tunggal yaitu: Sikap toleransi anak menghadapi konflik antar sesama siswa.

b. Definisi Konseptual

Konsep adalah istilah dan definisi yang digunakan untuk menggambarkan secara abstrak kejadian, keadaan, kelompok atau individu yang menjadi pusat perhatian ilmu sosial" (Singarimbun dan Effendi, 1995:33). Salah satu fungsi dari definisi konseptual untuk menghindari perbedaan penafsiran tentang variabel-variabel penelitian yang akan diuji antara konsep yang satu dengan konsep yang lain, agar tidak terjadi kesalahpahaman. Konsep merupakan unsur pokok dari suatu penelitian, kalau masalah dan kerangka teoritisnya sudah jelas biasanya sudah diketahui pula faktanya mengenai gejala-gejala yang menjadi pokok perhatian, 
dan suatu konsep sebenarnya adalah definisi secara singkat dari kelompok fakta atau gejala yang dimaksud. Definisi konseptual yang digunakan dalam penelitian ini adalah sebagai berikut:

1) “Sikap adalah pandangan atau kecenderungan mental” (Muhibbin Syah, 2004)

2) Toleransi adalah suatu sikap tenggang rasa atau saling menghormati kepada sesamanya $(\mathrm{KBBI})$.

3) "Konflik antar sesama adalah hubungan antara dua pihak atau lebih (individu atau kelompok) yang memiliki atau merasa memiliki tujuan-tujuan yang tidak sejalan” (Mitchell, 1996).

4) Sikap toleransi anak menghadapi konflik antar sesama siswa adalah pandangan atau kecenderungan mental dari seorang siswa dalam menghadapi hubungan dengan siswa lain yang berbeda tujuan.

\section{Definisi Operasional dan Subyek Penelitian}

Definisi operasional adalah unsur penelitian yang memberitahukan bagaimana caranya mengukur suatu variabel" (Singarimbun dan Effendi, 1995:46). Definisi tersebut menunjuk pada suatu informasi ilmiah yang amat membantu peneliti lain yang ingin menemukan variabel sama.

\begin{tabular}{|c|c|c|}
\hline Variabel yang diteliti & Sub Variabel & Indikator \\
\hline \multirow[t]{3}{*}{$\begin{array}{l}\text { Sikap toleransi } \\
\text { anak menghadapi } \\
\text { konflik antar } \\
\text { sesama siswa }\end{array}$} & $\begin{array}{l}\text { memahami } \\
\text { kepentingan } \\
\text { teman }\end{array}$ & $\begin{array}{l}\text { Mengetahui perbedaan kepentingan } \\
\text { 1) Mampu } \\
\text { 2) Tidak mampu } \\
\text { Mengompromikan dengan siswa lain } \\
\text { 1) Mampu } \\
\text { 2) Tidak mampu }\end{array}$ \\
\hline & $\begin{array}{l}\text { Menghormati } \\
\text { pendapat orang } \\
\text { lain }\end{array}$ & $\begin{array}{l}\text { Siswa menilai pendapat siswa lain } \\
\text { 1) Mampu } \\
\text { 2) Tidak mampu } \\
\text { Siswa menerima pendapat siswa lain } \\
\text { 1) Mampu } \\
\text { 2) Tidak mampu }\end{array}$ \\
\hline & $\begin{array}{l}\text { Siswa menerima } \\
\text { kelebihan dan } \\
\text { Kekurangan orang } \\
\text { lain }\end{array}$ & $\begin{array}{l}\text { Siswa menerima kebenaran pendapat } \\
\text { siswa lain } \\
\text { 1) Mampu } \\
\text { 2) Tidak mampu } \\
\text { Siswa memberikan saran atas kekurangan } \\
\text { orang lain } \\
\text { 1) Mampu } \\
\text { 2) Tidak mampu }\end{array}$ \\
\hline
\end{tabular}


Subjek penelitian yang dipilih untuk penelitian adalah siswa kelas VIII dan guru kelas VIII SMP Bhina Karya Rongkop Kabupaten Gunungkidul Yogyakarta, sebanyak 18 siswa dan guru Pkn sebanyak 1 orang.

\section{Pengumpulan Data}

Pengumpulan data dalam penelitian ini menggunakan dua teknik yaitu: observasi dan wawancara.

a. Observasi, Observasi dilakukan selama 2 minggu pada bulan Agustus 2014. Hambatan yang muncul dalam observasi adalah peneliti tidak bisa melakukan observasi selama terus menerus selama siswa berada di sekolah. Hal ini dikarenakan peneliti tidak bisa meninggalkan sepenuhnya tugas sebagai tenaga pendidik di SMP Bhina Karya Rongkop Kabupaten Gunungkidul Yogyakarta. Observasi hanya dilakukan sebanyak 4 kali, yaitu : pada hari Selasa tanggal 19 Agustus 2014 pada hari Jum'at tanggal 22 Agustus 2014 pada hari Senin tanggal 25 Agustus 2014 dan pada hari Kamis tanggal 28 Agustus 2014.

b. Interview (wawancara). Wawancara dilakukan kepada guru kelas untuk memperoleh data yang berkaitan dengan proses pembelajaran di kelas, terutama dalam hal gambaran umum sikap toleransi anak menghadapi konflik antar sesama siswa dengan menggunakan teori belajar. Hambatan yang ditemui dalam penelitian ini adalah peneliti merasa kesulitan untuk melakukan wawancara dengan siswa. Hal ini dikarenakan siswa sering kali tidak mau menjawab pertanyaan yang diberikan oleh peneliti. Untuk mengatas masalah tersebut maka interview dilakukan hanya kepada guru kelas PKn SMP Bhina Karya Rongkop Kabupaten Gunungkidul Yogyakarta.

\section{Teknik Analisis Data}

Menurut Miles dan Huberman (1992: 16-19) langkah-langkah dalam analisis data dengan pendekatan kualitatif adalah reduksi data, display data, dan penarikan kesimpulan. Ketiga langkah-langkah tersebut dapat dijabarkan sebagai berikut:

a. Reduksi data. Reduksi data diartikan sebagai proses pemilihan, pemisahan, perbaikan dan penyederhanaan, pengabstrakan serta transformasi data kasar yang muncul ddari catatan tertulis di lapangan. 
b. Display data atau penyajian data. Display data atau penyajian data sebagai sekumpulan informasi tersusun yang memberi kemungkinan penarikan kesimpulan, verifikasi dan pengambilan tindakan.

c. Penarikan kesimpulan/verifikasi

Penarikan kesimpulan/verifikasi merupakan upaya-upaya yang luas untuk menempatkan salman suatu temuan dalam seperangkat data yang lain.

\section{Hasil Penelitian dan Pembahasan}

Bahwa SMP Bhina Karya ini terletak di Kencamatan Rongkop Kabupaten Gunungkidul keadaan tenaga pengajar sudah cukup memenuhi persyaratan.

Untuk lebih jelas keadaan guru di SMP Bhina Karya adalah sebagai berikut:

\begin{tabular}{|l|l|l|}
\hline No & Nama & Bidang Tugas \\
\hline 1 & B. Dwi Wasono,SPd & Matematika \\
\hline 2 & Sunarno, S.Pd & IPA \\
\hline 3 & Tukini, S.Pd.K & Pendidikan Agama Kristen \\
\hline 4 & Ary Palupi, S.Pd & PKn \\
\hline 5 & Sularno & IPS \\
\hline 6 & Emiyati & Keterampilan \\
\hline 7 & P. Parman & IPS \\
\hline 8 & Hari Agus, S.SIP & IPA \\
\hline 9 & Praworo, S.Si & Bahasa Jawa \\
\hline 10 & Suparta & Penjas Orkes \\
\hline 11 & Eka Supriyanta & Matematika \\
\hline 12 & Yomi, S.Si & Bahasa Inggris \\
\hline 13 & Tuti Siti, W.S.Pdi & Pendidikan Agama Islam \\
\hline 14 & Puji Widodo & TIK \\
\hline 15 & Indra Dwi R. S.Pd & IPA \\
\hline 16 & Ribut Budianto, S.Pd & BK \\
\hline
\end{tabular}

Sumber dari monografi

Sedangkan Data Siswa SMP Bhina Karya adalah sebagai berikut:

Kelas VII berjumlah $\quad=25$ siswa

Kelas VIII berjumlah $\quad=18$ siswa

Kelas IX berjumlah $\quad=17$ siswa

Jadi jumlah siswa keseluruhan SMP Bhina Karya adalah 60 siswa 


\section{Sikap Toleransi Anak Menghadapi Konflik antar Sesama}

a. Mengetahui Perbedaan Kepentingan

Siswa mampu mengetahui tujuan dari siswa lain yang berbeda kepentingan. Hal tersebut terlihat dari beberapa contoh perilaku seperti Siswa mampu menghargai pendapat siswa lain, siswa mampu memberikan kesempatan kepada siswa lain untuk mengutarakan pendapatnya. Namun demikian, ada siswa yang belum mampu mengetahui tujuan dan siswa lain yang berbeda kepentingan. Hal tersebut terlihat dari beberapa contoh perilaku masa bodoh dengan siswa lain dan sifat egois (pokoknya aku dulu). Hal tersebut terungkap dari hasil wawancara dengan guru PKn Ari Palupi,SPd pada hari jumat tanggal 22 September 2014 sebagai berikut: "Ada siswa yang mampu dan belum mampu mengetahui tujuan siswa lain yang berbeda kepentingan waktu pelajaran di kelas dari sedang mendengar pelajaran yang diterangkan guru kelas, Ito yang satu meja dengan Dan duduk tenang juga memperhatikan pelajaran yang disampaikan oleh guru, tetapi ada satu anak (Fajar) selalu mengajak bicara walaupun duduknya di depannya Setiap pelajaran mesti begitu walaupun berkali-kali sudah ditegur dam diulangi lagi". (Hasil wawancara dengan Ari Palupi,SPd selaku guru Kelas pada hari Jum'at tanggal 22 September 2014.

Berdasarkan hasil wawancara dan observasi, terkadang terdapat perbedaan kepentingan antara siswa. Adanya perbedaan pendapat, perbedaan kepentingan merupakan suatu yang wajar. Anak harus disadarkan bahwa untuk mengatasi perbedaan pendapat dan kepentingan harus dipilih dialog dan bukan dengan kekerasan. Mereka dilatih dialog, memberi dan menerima di mana banyak sudut pandang yang berbeda dikemukakan dan dihargai. Dengan cara ini mereka makin mengalami betapa baiknya sumbangan yang berbeda-beda demi kebaikan hidup bersama. Pendidikan berdialog ini penting, mengingat anak-anak bersifat egosentris sehingga tidak mudah bagi mereka untuk menghargai teman-teman lain dan berbuat untuk kebaikan teman. Mereka juga cenderung berpikir terbatas sehingga sulit mengerti sudut pandang orang lain. Mereka juga sulit menyadari bahwa tindakannya bisa berimajinasi tentang apa yang tidak dapat mereka lihat. Bila ada perselisihan atau pertengkaran di antara mereka, pendidik harus berkata bahwa tidak boleh saling memukul tetapi perlu menggunakan kata-kata bila mereka sedang merah. Juga perlu dikatakan tentang perlunya bergiliran omong untuk memberi kesempatan bagi yang lain mengemukakan pikiran atau perasaan, juga perlu time out (berhenti sementara) agar mereka dapat tenang atau sejuk hati dan punya waktu untuk berpikir ulang tentang apa yang sudah terjadi. 
b. Mengkompromikan Dengan Siswa Lain

Ada siswa yang mampu mengkompromikan tujuannya sendiri dengan tujuan siswa lain. Hal tersebut terlihat dari beberapa contoh perilaku seperti dalam diskusi kelompok mau menerima masukan / saran siswa lain dan dalam memutuskan sesuatu minta pendapat siswa lain. Namun demikian, ada siswa yang belum mampu mengkompromikan tujuannya sendiri dengan tujuan siswa lain. Hal tersebut terlihat dari beberapa contoh perilaku seperti dalam kerja kelompok, dalam menentukan tempat dan waktu dan waktu ketua kelompok memutuskan sendiri. Selain itu siswa merasa bisa tugas kelompok dikerjakan sendiri. Hal tersebut terungkap dari hasil wawancara dengan guru kelas sebagai berikut:

"Memang di kelas VIII, ada yang sudah mampu mengkompromikan tujuan sendiri sesuai dengan tujuan siswa lain, tetapi masih ada juga yang belum mampu, contohnya ya Pak waktu saya memberi tugas kelompok, setiap kelompok terdiri dari 6 siswa. Dalam memilih tugas yang saya berikan kelompoknya Sari berembuk dulu baru memilih tugasnya tetapi kelompoknya Tejo karena merasa dipilih sebagai ketua dia langsung memilih sendiri walaupun semua temannya setuju dengan pilihannya". (Hasil wawancara dengan Ari Palupi,SPd selaku guru Kelas pada hari Jum'at tanggal 22 September 2014

Agar siswa mampu mengompromikan ide/gagasan dengan siswa lain maka siswa perlu berlatih untuk melakukan diskusi. Diskusi bertujuan untuk tukar menukar gagasan, pemikiran, informasi, pengalaman di antara siswa sehingga dicapai kompromi atau kesepakatan pokok-pokok pikiran (gagasan, ide, kesimpulan) dan mengembangkan kesamaan pendapat atau kesepakatan untuk mencari suatu keputusan terbaik mengenai suatu permasalahan. Untuk mencapai kompromi atau kesepakatan tersebut para siswa beradu argumentasi untuk meyakinkan siswa lain. Kesepakatan pikiran inilah yang nantinya dicatat sebagai hasil diskusi.

Faktor yang mendorong siswa berpartisipasi dalam diskusi dan tanya jawab adalah usaha untuk mengetahui realitas tidaknya pemikiran bila dikaji dengan pengalaman dan pemikiran siswa lain. Diskusi sebagai salah satu cara penyajian pelajaran memiliki maksud untuk memotivasi aktivitas dan kreativitas siswa di sekolah. Pertanyaan 
yang baik adalah pertanyaan yang dapat mengarahkan pelajaran untuk mencapai tujuan pembelajaran. Diskusi merupakan media yang digunakan oleh guru bersama para siswa untuk mencari pemecahan atas persoalan yang dihadapi.

\section{Menghormati Pendapat Orang Lain}

a. Menilai Pendapat Siswa Lain

Ada siswa yang bersedia menilai pendapat siswa lain. Hal tersebut terlihat dari beberapa contoh perilaku seperti dalam menanggapi pertanyaan guru, siswa berani menyanggah jawaban siswa lain. Selain itu beberapa siswa juga berani memberi komentar mengenai jawaban siswa lain. Namun demikian, ada siswa yang belum mampu menilai pendapat siswa lain. Hal tersebut terlihat dari beberapa contoh perilaku seperti siswa memang pasif dalam menentukan tempat dan waktu dan siswa tidak tertarik suatu diskusi. Hal tersebut terungkap dari hasil wawancara dengan guru kelas sebagai sebagai berikut:

"Di kelas VIII jumlahnya siswanya 18 memang ada yang mau menilai pendapat siswa lain, tetapi juga banyak yang tidak mau menilai pendapat siswa lain terutama anak laki-laki dengan anak perempuan, kalau anak perempuan sebagian besar mau menilai pendapat siswa lain tetapi kalau anak laki-laki kebanyakan masa bodoh dengan pendapat anak perempuan". (Hasil wawancara dengan Ari Palupi selaku guru Kelas pada hari Jumat tanggal 22 November 2012)

Dalam merumuskan persoalan-persoalan kritis salah jika kita memahami bahwa diskusi bukan sebagai suatu proses peradilan di mana salah satu pihak dianggap sebagai pihak yang salah, sedangkan pihak yang lain dianggap sebagai pihak yang benar.

b. Menerima Pendapat Siswa Lain

Ada siswa yang mampu menilai pendapa siswa lain, benar atau salah. Hal tersebut terlihat dari beberapa contoh perilaku seperti dalam menjawab pertanyaan guru, siswa mampu menyalahkan atau membenarkan jawaban siswa lain. Selain itu perilaku tersebut terlihat dalam ulangan, banyak siswa yang sadar bahwa menyontek itu salah, belajar rajin itu yang benar. Namun demikian, ada siswa yang belum mampu menilai pendapat siswa lain itu benar atau salah. Hal tersebut terlihat dari beberapa contoh perilaku seperti mau diajak membolos mau dan melakukan suatu perbuatan yang salah karena mengikuti kelompok yang banyak. Hal tersebut terungkap dari hasil wawancara dengan guru kelas sebagai berikut:

"Kalau ditanya ada tidaknya siswa yang mampu dan belum mampu menilai pendapat siswa lain itu benar atau salah tentu ada, contohnya saja Tita memang anaknya pandai, dia tidak mudah 
terpengaruh dengan ajakan temannya, lain dengan Dandi, dia mudah terpengaruh teman apalagi yang mempengaruhi itu anaknya banyak. Contoh : diajak jajan di luar lingkungan sekolah". (Hasil wawancara dengan Ari Palupi selaku guru Kelas pada hari Jumat tanggal 25 November 2012).

Saat diskusi kelompok dan pengumpulan materi untuk presentasi, tampak para peserta didik memiliki kemampuan memberikan dan menerima pendapat. Para peserta didik juga melakukan pembagian tugas dengan baik dan bekerja sama untuk mencapai hasil. Kebanyakan dari siswa melatih diri dengan ikut aktif di organisasi, siswa. Namun banyak pula yang tidak sempat berorganisasi, mereka baru sadar akan kekurangan mereka dan langsung belajar dalam diskusi-diskusi. Siswa yang tidak terbiasa dalam suatu diskusi biasanya akan canggung dan belum terlatih akan membuat mereka sering menjadi "penonton diam". Siswa tersebut butuh waktu lebih lama untuk memperoleh keterampilan yang sederhana sekalipun. Oleh karena itu sebaiknya di usia yang masih muda mereka harus terbiasa untuk menerima pendapat orang lain. Dengan demikian ketika anak-anak menjadi dewasa, mereka akan lebih mudah diajak mencoba melihat suatu isu dari sudut pandang orang lain.

\section{Menerima Kelebihan dan Kekurangan Orang Lain}

a. Menerima Kebenaran

Ada siswa yang bersedia menerima kebenaran pendapat orang lain. Hal tersebut terlihat dari beberapa contoh perilaku seperti dengan senang hati siswa mengikuti keputusan bersama walaupun pendapatnya tidak dipakai, bahkan tidak jarang siswa mau mengakui kesalahan. Namun demikian, ada siswa yang belum bersedia menerima kebenaran pendapat orang lain. Hal tersebut terlihat dari beberapa contoh perilaku seperti melaksanakan keputusan bersama tetapi tidak dengan sepenuh hati (merasa terpaksa) atau dalam melaksanakan tugas tidak bersemangat. Hal tersebut terlihat dari hasil wawancara dengan guru kelas sebagai berikut:

"Mengenai siswa bersedia menerima kebenaran pendapat siswa lain dan yang belum bersedia menerima kebenaran pendapat siswa lain dan yang belum bersedia menerima itu pasti ada, mengenai contohnya karena saya sebagai guru kelas sering minta pendapatnya (siswa) dan menentukan warna seragam olahraga, ada yang ngotot mempertahankan pendapatnya tapi ada juga yang terus setuju dengan keputusan". (Hasil wawancara dengan Ari Palupi selaku guru Kelas pada hari Jum'at tanggal 25 November 2012). 
Sering terjadi dalam suatu diskusi akhirnya bukan diskusi tapi bantah membantah, sebab kalau yang namanya diskusi itu pikirannya terpusat pada pembahasan yang sedang dibahas. Kalau ada pendapat-pendapat yang menyimpang dan pembahasan, pendapat itu tidak dihina, tidak dilecehkan, tidak direndahkan. Tetapi pendapat itu tidak dipakai dan tidak dimunculkan, yang dimunculkan adalah pendapat yang terkait dengan bahasan suatu masalah.

c. Memberikan Saran Atas Kekurangan Orang Lain

Ada siswa yang bersedia memberikan saran atas kekurangan orang lain. Hal tersebut terlihat dari beberapa contoh perilaku seperti bersedia memberikan masukan atau pendapat orang lain yang kurang lengkap dan bersedia memberi respons atas pendapat orang lain. Namun demikian, ada siswa yang belum bersedia memberikan saran atas kekurangan orang lain mungkin memang tidak tahu apa maksudnya. Hal tersebut terlihat dari beberapa contoh perilaku seperti siswa yang cenderung bersikap pasif dan siswa yang tidak mampu mengungkapkan saran kepada siswa yang lain. Hal tersebut terungkap dari hasil wawancara dengan guru kelas sebagai berikut:

"Ada siswa yang bersedia memberikan saran atas kekurangan orang lain tetapi banyak yang belum bisa memberi saran, contoh yang mudah ya Pak, waktu istirahat, anak-anak makan jajajan yang bungkusnya dibuang sembarangan, ada anak tahu itu salah, disuruh dimasukkan ke tempat sampah, tapi ada juga siswa yang diam saja walaupun temanya itu membuang sampah sembarangan”. (Hasil wawancara dengan Ari Palupi selaku guru Kelas pada hari Jum'at tanggal 25 November 2012).

Haruslah siswa diingatkan bahwa bahkan orang yang paling baik sekalipun akan memiliki kekurangan, dan kita tidak boleh terlalu menuntut dari orang lain. Siswa perlu sangat sabar dengan kekurangan orang lain. Orang yang paling sempurna di dunia ini juga masih mempunyai banyak kekurangan, begitu juga dengan diri kita sendiri.

Kesimpulan

Berdasarkan hasil penelitian dan analisis data yang tersaji pada Bab IV, maka dapat dibuat kesimpulan sebagai berikut:

1. Memahami Kepentingan Teman

a. Mengetahui perbedaan kepentingan. Siswa mampu mengetahui tujuan dari siswa lain yang berbeda kepentingan. 
b. Mengkompromikan dengan siswa lain. Siswa yang mampu mengkompromikan tujuannya sendiri dengan tujuan siswa lain.

2. Menghormati Pendapat Orang Lain

a. Menilai pendapat siswa lain. Siswa yang bersedia menilai pendapat siswa lain.

b. Menerima pendapat siswa lain. Siswa yang mampu menilai pendapat siswa lain, benar atau salah.

3. Menerima Kelebihan dan Kekurangan Orang Lain

a. Menerima kebenaran. Siswa yang bersedia menerima kebenaran pendapat orang lain.

b. Memberikan saran atas kekurangan orang lain. Siswa yang bersedia memberikan saran atas kekurangan orang lain.

\section{Daftar Pustaka}

Masri Singarimbun dan Sofyan Effendi, 1989. Metode Penelitian Survey. Jakarta : LP3ES.

Muhaemin E1-Ma'hady, 2004. Multikulturalisme dan Pendidikan Multikultural. Artikel. 27 mei 2004. Diakses dari situs http://re-searchengines.com/muhaemin6-04.htm1

Ramlan Surbakti, 1992. Memahami Ilmu Politik, Jakarta : PT. Gramedia,

Suharsimi Arikunto, 1988. Organisasi dan Administrasi Pendidikan Teknologi dan Kejuruan. Jakarta: Departemen Pendidikan dan Kebudayaan RI

Timur Mahardika, 2000. Gerakan Massa mengupayakan Demokrasi dan KeadiIan Sosial Secara Damai, Yogyakarta: Lapera Pustaka Utama. 